\title{
Jet Lagging in Abrasive Water Jet Cutting of High-Speed Tool Steel
}

\author{
Ramiz Kurbegovic ${ }^{1 *}$, Mileta Janjic ${ }^{1}$ \\ ${ }^{1}$ Faculty of Mechanical Engineering, University of Montenegro, Podgorica (Montenegro)
}

Abrasive water jet machining is a very efficient unconventional method for contour cutting of different types of materials. As one of the main characteristics of the quality of surfaces machined with this method is curved lines that appear during machining. These lines are a consequence of the deviation of the abrasive water jet from its ideal vertical line, jet lagging, which are the cause of machining errors.

The aim of this work is to investigate the influence of machining parameters on jet lagging. The samples of high-speed steel EN HS6-5-2 (JUS c.7680) were machined with an abrasive water jet under varying working pressure, traverse speed, abrasive mass flow rate, and stand-off distance. The jet lagging was measured at twenty places along with the depth of cut, and based on these results, the relationship between the jet lagging and machining parameters has been formed.

In order to correctly select the process parameters, an empirical model for the prediction of jet lagging in abrasive waterjet cutting of high-speed steel EN HS6-5-2 was developed using regression analysis. This developed model has been verified with the experimental results that reveal high applicability of the model within the experimental range used.

\section{Keywords: Jet lagging, Abrasive waterjet, Empirical model, High speed tool steel, Regression analysis}

\section{INTRODUCTION}

Abrasive Waterjet Cutting [AWJC] has various distinct advantages over the other non-conventional cutting technologies, such as no thermal distortion, high machining versatility, minimum stresses on the work piece, high flexibility and small cutting forces and has been proven to be an effective technology for processing various engineering materials [1]. It is superior to many other cutting techniques in processing variety of materials and has found extensive applications in industry [2]. However, AWJC has some drawbacks and limitations. It creates tapered edges on the kerf, especially when cutting at high traverse rates $[3,4]$, generate loud noise and a messy working environment.

In the abrasive water jet cutting, the tool is the abrasive water jet, Figure 1.

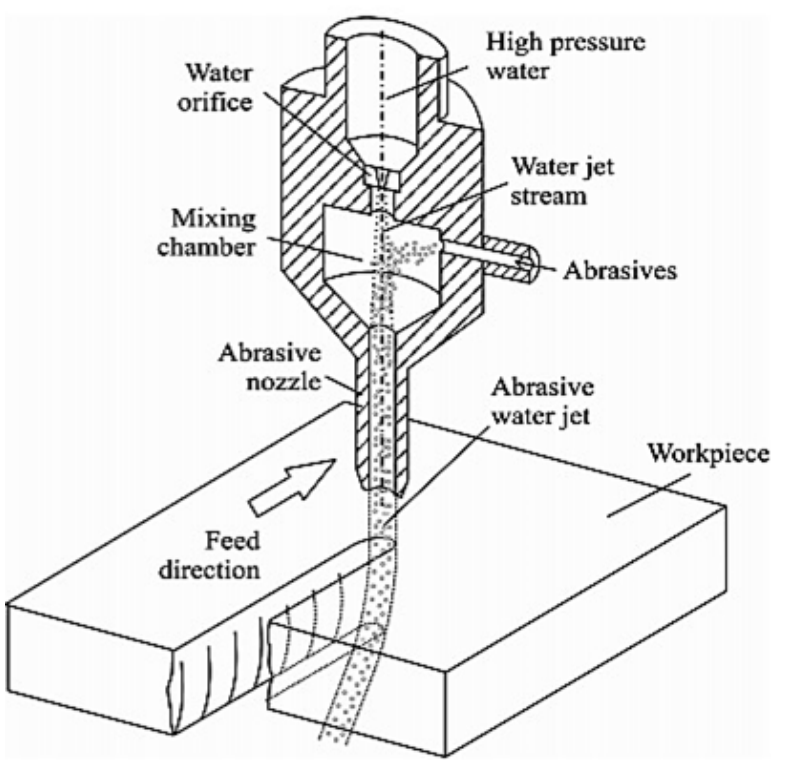

Figure 1: Schematic view of abrasive water jet cutting [5]

The abrasive water jet is a narrow, high-speed water jet stream, formed by highlighting the small diameter water orifice. Downstream from the orifice, in the mixing chamber, abrasive particles are added in the high-speed water jet. They are accelerated by momentum exchange with the high-speed water jet in an abrasive nozzle. From there, the abrasive water jet is directed to the work piece.

The principles on which the abrasive water jet machining process is based on is erosion. Some authors explain the process of erosion as a kind of abrasive wear, at which abrasive particles and water jet repeatedly impact the surface, resulting in flushing of the material from that surface $[2,6]$.

There are several papers dealing with the formation of cut front geometry and the factors that influence its final appearance. Mostly, the cutting front geometry of the workpiece machined by the abrasive water jet is influenced by machining parameters such as operating pressure, standoff distance, traverse speed, abrasive flow rate $[2,7]$.

Defining the geometry of the cutting front, is in fact, the determination of the deviation - lagging, $\mathbf{Y}_{\mathbf{l a g}}$, of the abrasive water jet from the vertical line. Momber and Kovačević [2] explained the deviation of the cut front geometry from ideal as a consequence of energy loss during the cutting process, Figure 2.

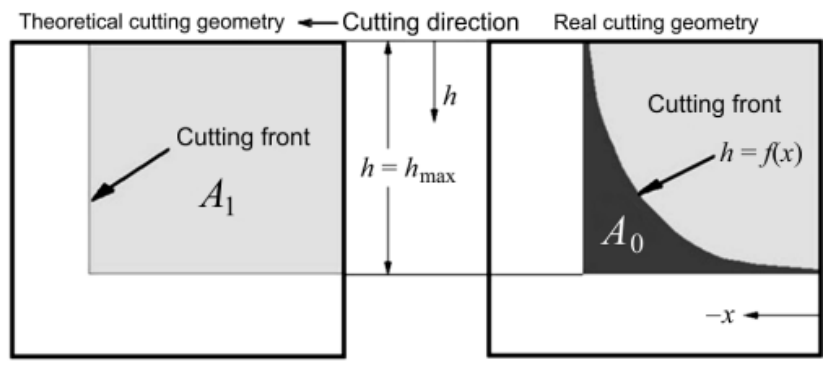

Figure 2: Deviation of the cut front geometry from ideal [2]

The line that defines the lagging of abrasive water jet is described by Zeng, Heines and Kim [8] as a parabola.

The aim of this work is to investigate the influence of machining parameters, such as operating pressure, $p$, standoff distance, $\mathrm{Sd}$, traverse speed, $\mathrm{U}$, and abrasive mass 
flow rate, Ma, on jet lagging and to make an empirical model for the prediction of jet lagging in abrasive waterjet cutting of high-speed steel EN HS6-5-2.

M. Chithirai Pon Selvan i N. Mohana Sundara Raju [9] observed the maximum cutting depth, $\mathrm{h}_{\max }$, as a main parameter for evaluating the applicability of the abrasive water jet machining process for a particular material. They found that water pressure has the most effect on the depth of cut and surface roughness. An increase in water pressure is associated with an increase in depth of cut but a decrease in surface roughness. Depth of cut constantly increases and surface roughness decreases as mass flow rate increases. As nozzle traverse speed increase, surface roughness increases but depth of cut decreases. This means that low traverse speed should be used to have more depth of cut and surface smoothness but is at the cost of sacrificing productivity. This experimental study has resulted that standoff distance has no apparent effect on depth of cut. Nevertheless, surface smoothness increases as stand-off distance decreases. Using regression analysis, they developed a model for predicting the depth of cut of stainless steel. During the development of the model, various parameters of the abrasive water jet machining process were taken into account. Their model is represented by a formula:

$$
\mathrm{h}_{\max }=678 \cdot \frac{\mathrm{p}^{0,339} \cdot \mathrm{Ma}^{0,107} \cdot \mathrm{d}_{\mathrm{a}}{ }^{1,795} \cdot \rho_{\mathrm{a}}{ }^{0,878}}{\mathrm{E}^{0,324} \cdot \mathrm{U}^{0,137} \cdot \mathrm{Sd}^{0,009} \cdot \rho_{\mathrm{w}} \cdot \mathrm{d}_{\mathrm{j}}}
$$

where $\mathbf{p}$ is the working pressure, $\mathbf{M a}$ is the abrasive mass flow rate, $\mathbf{d}_{\mathbf{a}}$ is the mean value of the abrasive particle diameter, $\boldsymbol{\rho}_{\mathbf{a}}$ is the density of the abrasive particles, $\mathbf{E}$ is the material modulus of elasticity, $\mathbf{U}$ is the traverse speed, $\mathbf{S d}$ is the stand-off distance of the cutting head from the workpiece, $\boldsymbol{\rho}_{\mathbf{w}}$ is the density of the water and $\mathbf{d}_{\mathbf{j}}$ is the diameter of the water jet.

This model showed a good corelation with the experimentally obtained results and will be used as a basis for experimental analysis of the influence of the machining process parameters on the jet lagging.

\section{EXPERIMENTAL WORK}

Samples presented by Kurbegovic, Janjic, Vukcevic and Durovic [10], Table 1, concerning the influence of the water pressure (p), traverse speed $(\mathbf{U})$, abrasive flow rate (Ma) and stand-off distance (Sd) on the abrasive water jet lagging, were used for creating relationships and adopting a mathematical model of influence of the machining process parameters on the jet lagging.

Table 1: Samples and its machining parameters [10]

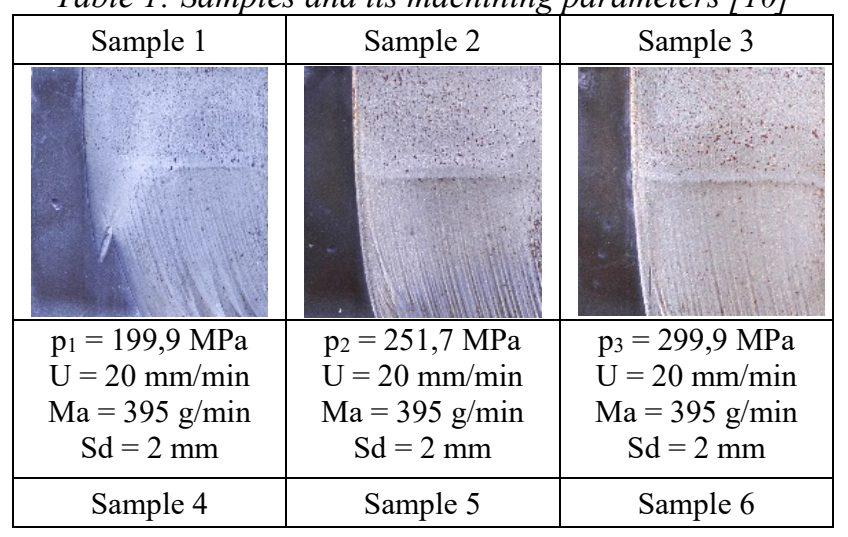

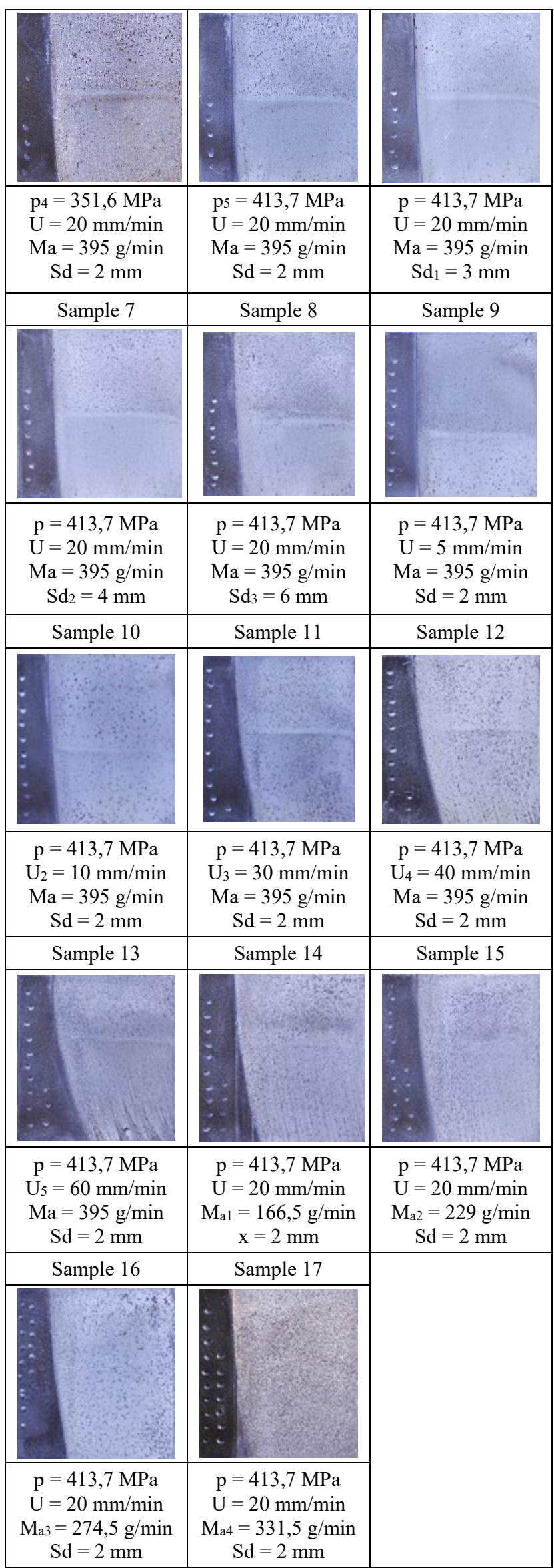

The system used for machining the samples is the product of WJS, model NCX 4020, Sweden. The diameter of the water orifice was $0,254 \mathrm{~mm}$ and the abrasive nozzle 
(focusing tube) diameter was $0,768 \mathrm{~mm}$ (ROCTEC 100). The abrasive material was Garnet mesh 80 .

The material used for the experiment is high-speed tool steel EN HS6-5-2 (JUS c.7680, AISI M2), produced with the Electro Slag Remelting (ESR) method in a roundshaped ingot, normalized, bandsawed to $42 \mathrm{~mm}$ thick discs and lathe cut to $40 \pm 0,05 \mathrm{~mm}$. Material is then water jet machined to a $40 \times 40 \times 110 \pm 0,05 \mathrm{~mm}$ specimens. The side which is water jet machined is milled and flatten to $38 \pm 0,05$ $\mathrm{mm}$ for distinction purposes. The material was cut to a length of $30 \mathrm{~mm}$. Then the flow of abrasives was stopped and then the machine was stopped. After that, the specimens were cut till the end with Wire Electric Discharge Machining (WEDM). Cutting with WEDM was done to avoid damaging the cut front line and that it could be possible to measure the jet lagging.

Measurements for determining water jet lagging were performed in twenty places (at the same distance) along the sample thickness using an optical microscope. Measurement principle of jet lagging is shown on Figure 3.

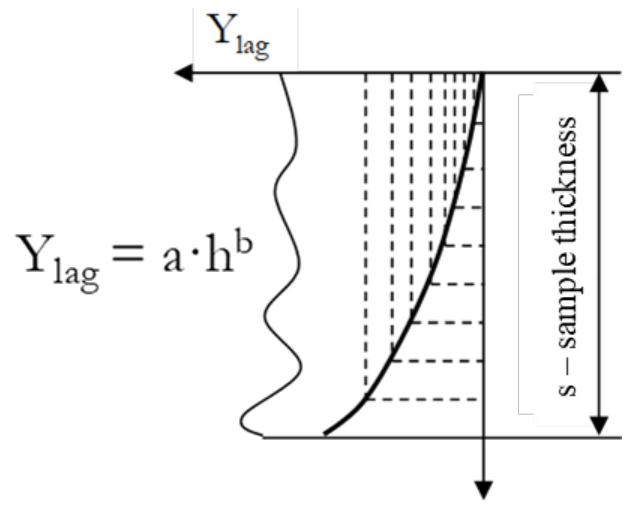

Figure 3: Measurement of jet lagging [11]

Measured values of jet lagging for samples shown in Table 1, are shown in Table 2.

Table 2: Measured values of jet lagging [10]

\begin{tabular}{|c|c|c|c|c|}
\hline & Sample 1 & Sample 2 & Sample 3 & Sample 4 \\
\hline $\begin{array}{c}\text { h, } \\
\mathbf{m m}\end{array}$ & \multicolumn{4}{|c|}{$\mathbf{Y a g}_{\mathbf{l a}}, \mathbf{m m}$} \\
\hline 0 & 0 & 0 & 0 & 0 \\
\hline 2 & 0,0978 & 0,0774 & 0,0693 & 0,0590 \\
\hline 4 & 0,1473 & 0,1294 & 0,1277 & 0,0804 \\
\hline 6 & 0,1554 & 0,1534 & 0,1661 & 0,1531 \\
\hline 8 & 0,2108 & 0,2133 & 0,2104 & 0,1865 \\
\hline 10 & 0,3152 & 0,2726 & 0,2436 & 0,2198 \\
\hline 12 & 0,4381 & 0,3314 & 0,2608 & 0,2537 \\
\hline 14 & 0,5450 & 0,4058 & 0,3066 & 0,3042 \\
\hline 16 & 0,6765 & 0,5350 & 0,4178 & 0,4162 \\
\hline 18 & 0,8117 & 0,6642 & 0,5569 & 0,5385 \\
\hline 20 & 1,0111 & 0,7969 & 0,6451 & 0,6536 \\
\hline 22 & 1,2282 & 0,9297 & 0,8191 & 0,7461 \\
\hline 24 & 1,4628 & 1,1341 & 0,9932 & 0,8241 \\
\hline 26 & 1,7640 & 1,3384 & 1,1247 & 0,9159 \\
\hline 28 & 2,0834 & 1,5427 & 1,2561 & 1,0661 \\
\hline 30 & 2,5039 & 1,8170 & 1,3876 & 1,2163 \\
\hline 32 & - & 2,0914 & 1,6424 & 1,4484 \\
\hline 34 & - & 2,4332 & 1,8973 & 1,6805 \\
\hline 36 & - & 2,8380 & 2,1376 & 1,9127 \\
\hline 38 & - & 3,2731 & 2,4666 & 2,1448 \\
\hline 40 & - & 3,8638 & 2,7958 & 2,3769 \\
\hline & & & & \\
\hline
\end{tabular}

\begin{tabular}{|c|c|c|c|c|}
\hline & Sample 5 & Sample 6 & Sample 7 & Sample 8 \\
\hline $\begin{array}{c}\text { h, } \\
\text { mm }\end{array}$ & \multicolumn{4}{|c|}{$\mathbf{Y}_{\text {lag }}, \mathbf{m m}$} \\
\hline 0 & 0 & 0 & 0 & 0 \\
\hline 2 & 0,0453 & 0,0651 & 0,0709 & 0,0703 \\
\hline 4 & 0,0906 & 0,1303 & 0,1418 & 0,1407 \\
\hline 6 & 0,1359 & 0,1954 & 0,2126 & 0,2110 \\
\hline 8 & 0,1811 & 0,2309 & 0,2571 & 0,2813 \\
\hline 10 & 0,2264 & 0,2754 & 0,3016 & 0,3517 \\
\hline 12 & 0,2717 & 0,3198 & 0,3329 & 0,4220 \\
\hline 14 & 0,3170 & 0,3643 & 0,3708 & 0,4923 \\
\hline 16 & 0,3623 & 0,4087 & 0,4087 & 0,5627 \\
\hline 18 & 0,4076 & 0,4624 & 0,5130 & 0,6330 \\
\hline 20 & 0,4786 & 0,5160 & 0,6173 & 0,7033 \\
\hline 22 & 0,5329 & 0,6443 & 0,7217 & 0,8407 \\
\hline 24 & 0,6382 & 0,7726 & 0,8260 & 0,9782 \\
\hline 26 & 0,7434 & 0,9107 & 0,9803 & 1,1337 \\
\hline 28 & 0,8487 & 1,0489 & 1,1346 & 1,2892 \\
\hline 30 & 0,9539 & 1,1871 & 1,2890 & 1,4448 \\
\hline 32 & 1,1120 & 1,3642 & 1,5121 & 1,6671 \\
\hline 34 & 1,2701 & 1,5414 & 1,7351 & 1,8894 \\
\hline 36 & 1,4282 & 1,7185 & 1,9582 & 2,1116 \\
\hline 38 & 1,5863 & 1,8957 & 2,1813 & 2,3339 \\
\hline 40 & 1,7445 & 2,0729 & 2,4045 & 2,5563 \\
\hline & Sample 9 & $\begin{array}{c}\text { Sample } \\
10\end{array}$ & $\begin{array}{c}\text { Sample } \\
11\end{array}$ & $\begin{array}{c}\text { Sample } \\
12\end{array}$ \\
\hline
\end{tabular}

\begin{tabular}{|c|c|c|c|c|}
\hline $\begin{array}{l}\text { h, } \\
\text { mm }\end{array}$ & \multicolumn{4}{|c|}{$\mathbf{Y}_{\text {lag, }} \mathbf{m m}$} \\
\hline 0 & 0 & 0 & 0 & 0 \\
\hline 2 & 0 & 0 & 0,0926 & 0,0926 \\
\hline 4 & 0 & 0 & 0,1852 & 0,1852 \\
\hline 6 & 0 & 0 & 0,2777 & 0,2777 \\
\hline 8 & 0 & 0 & 0,3703 & 0,3703 \\
\hline 10 & 0 & 0,0329 & 0,4351 & 0,4351 \\
\hline 12 & 0 & 0,0658 & 0,5232 & 0,6626 \\
\hline 14 & 0 & 0,1023 & 0,6245 & 0,8925 \\
\hline 16 & 0,0393 & 0,1389 & 0,8342 & 1,1718 \\
\hline 18 & 0,0786 & 0,2365 & 1,0439 & 1,4512 \\
\hline 20 & 0,1179 & 0,3342 & 1,3387 & 1,8412 \\
\hline 22 & 0,1572 & 0,4319 & 1,6336 & 2,2312 \\
\hline 24 & 0,1965 & 0,5532 & 1,9633 & 2,6259 \\
\hline 26 & 0,2359 & 0,6744 & 2,2930 & 3,0207 \\
\hline 28 & 0,2752 & 0,7631 & 2,7636 & 3,5046 \\
\hline 30 & 0,3289 & 0,9202 & 3,2342 & 3,9984 \\
\hline 32 & 0,3826 & 1,0672 & 3,7047 & 4,4723 \\
\hline 34 & 0,4363 & 1,2141 & 4,1753 & 4,9562 \\
\hline 36 & 0,5485 & 1,3298 & 4,6183 & 5,4635 \\
\hline 38 & 0,6608 & 1,5612 & 5,0612 & 5,9708 \\
\hline \multirow[t]{2}{*}{40} & 0,7730 & 1,6769 & 5,5042 & 6,4779 \\
\hline & $\begin{array}{c}\text { Sample } \\
13\end{array}$ & $\begin{array}{c}\text { Sample } \\
14\end{array}$ & $\begin{array}{c}\text { Sample } \\
15\end{array}$ & $\begin{array}{c}\text { Sample } \\
16\end{array}$ \\
\hline $\begin{array}{c}\mathbf{h}, \\
\mathbf{m m}\end{array}$ & \multicolumn{4}{|c|}{$\mathbf{Y}_{\text {lag, }}, \mathbf{m m}$} \\
\hline 0 & 0 & 0 & 0 & 0 \\
\hline 2 & 0,0926 & 0,0926 & 0,0926 & 0,0834 \\
\hline 4 & 0,1852 & 0,1852 & 0,1852 & 0,1668 \\
\hline 6 & 0,2777 & 0,2777 & 0,2777 & 0,2503 \\
\hline 8 & 0,3703 & 0,3703 & 0,3703 & 0,3439 \\
\hline 10 & 0,5809 & 0,4715 & 0,4715 & 0,4175 \\
\hline 12 & 0,7997 & 0,6278 & 0,6278 & 0,4691 \\
\hline
\end{tabular}




\begin{tabular}{|c|c|c|c|c|}
\hline 14 & 1,1137 & 0,8224 & 0,7458 & 0,5187 \\
\hline 16 & 1,4497 & 1,0830 & 0,9277 & 0,7437 \\
\hline 18 & 1,7856 & 1,4235 & 1,0865 & 0,9907 \\
\hline 20 & 2,3621 & 1,7762 & 1,3359 & 1,2030 \\
\hline 22 & 2,9387 & 2,1288 & 1,5853 & 1,4153 \\
\hline 24 & 3,4368 & 2,5145 & 1,8378 & 1,7352 \\
\hline 26 & 4,0273 & 2,8689 & 2,0485 & 2,0485 \\
\hline 28 & 4,6854 & 3,2476 & 2,3667 & 2,3667 \\
\hline 30 & 5,3470 & 3,6263 & 2,6848 & 2,6848 \\
\hline 32 & 6,0086 & 4,0051 & 3,0029 & 3,0029 \\
\hline 34 & 6,6703 & 4,3838 & 3,321 & 3,3210 \\
\hline 36 & 7,5399 & 4,9571 & 3,8172 & 3,6890 \\
\hline 38 & 8,4366 & 5,5929 & 4,3531 & 3,9815 \\
\hline \multirow[t]{2}{*}{40} & 9,3471 & 6,1071 & 4,8004 & 4,1935 \\
\hline & $\begin{array}{c}\text { Sample } \\
17\end{array}$ & & & \\
\hline $\begin{array}{l}\mathbf{h}, \\
\mathbf{m m}\end{array}$ & $\mathbf{Y}_{\text {lag }}, \mathbf{m m}$ & & & \\
\hline 0 & 0 & & & \\
\hline 2 & 0,0410 & & & \\
\hline 4 & 0,0820 & & & \\
\hline 6 & 0,1229 & & & \\
\hline 8 & 0,1639 & & & \\
\hline 10 & 0,2962 & & & \\
\hline 12 & 0,4284 & & & \\
\hline 14 & 0,5606 & & & \\
\hline 16 & 0,6928 & & & \\
\hline 18 & 0,8251 & & & \\
\hline 20 & 0,9999 & & & \\
\hline 22 & 1,1748 & & & \\
\hline 24 & 1,3876 & & & \\
\hline 26 & 1,7095 & & & \\
\hline 28 & 2,0332 & & & \\
\hline 30 & 2,3569 & & & \\
\hline 32 & 2,6806 & & & \\
\hline 34 & 3,0043 & & & \\
\hline 36 & 3,3133 & & & \\
\hline 38 & 3,6340 & & & \\
\hline 40 & 3,9440 & & & \\
\hline
\end{tabular}

It was concluded in [10] and shown on figure 2 that as the cutting depth increases, the deviation of the front cutting line from its ideal line, jet lagging, also increases. The increase in traverse speed and the distance of the cutting head from the machining material, stand-off distance, results in an increase of the jet lagging. As the values of the abrasive flow and working pressure processing parameters increase, the jet lagging decreases. This clearly demonstrates the strong correlation between the jet lagging and the applied machining parameters.

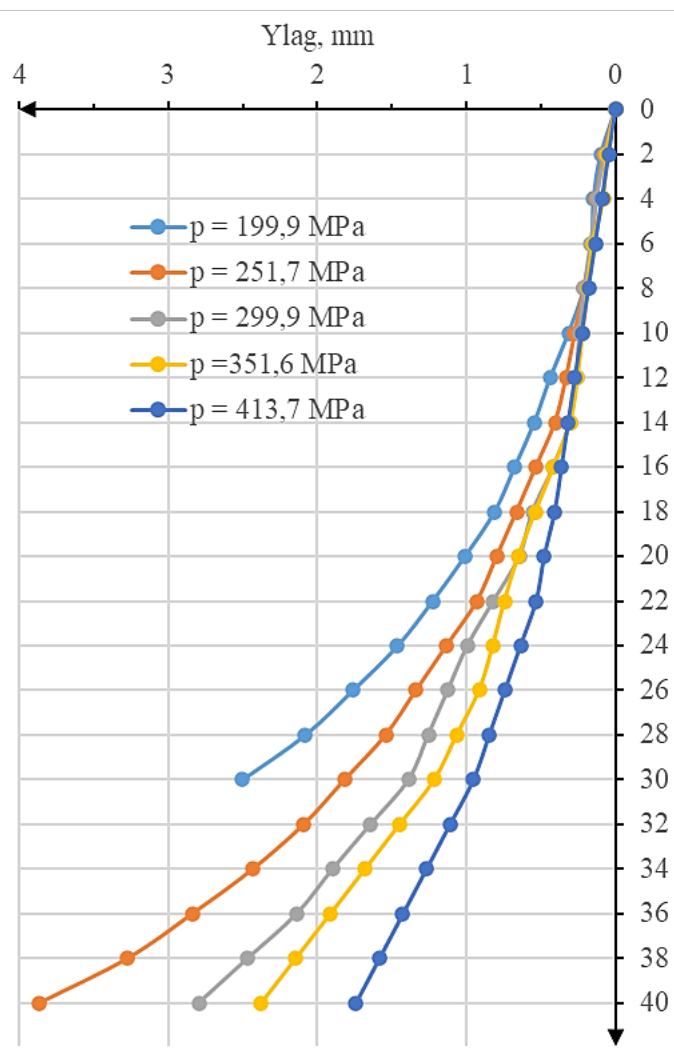

(a)

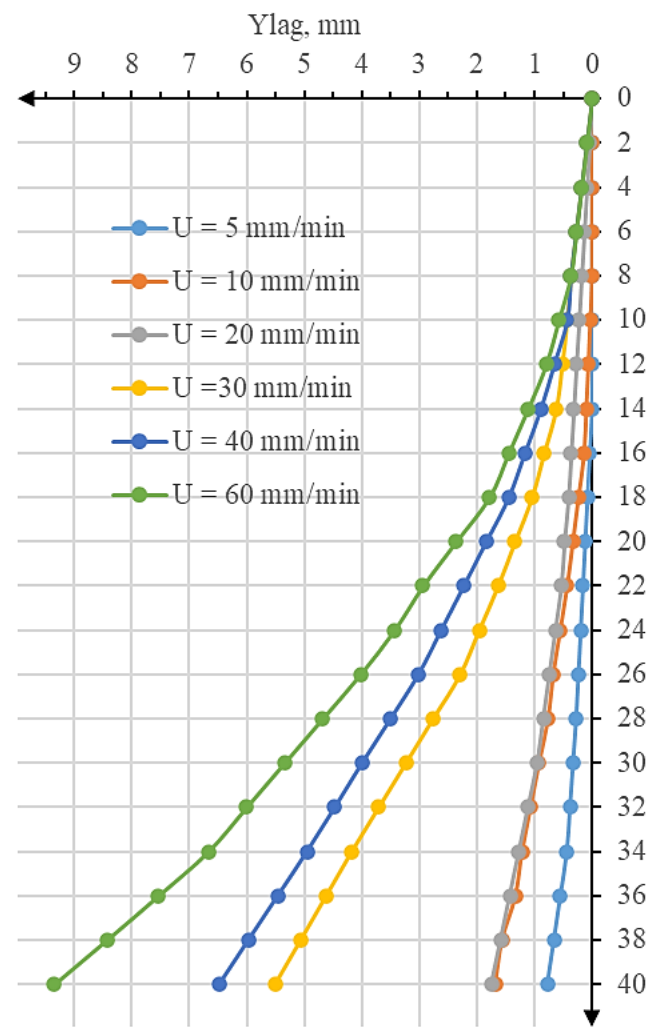

h, $\mathrm{mm}$

(b) 


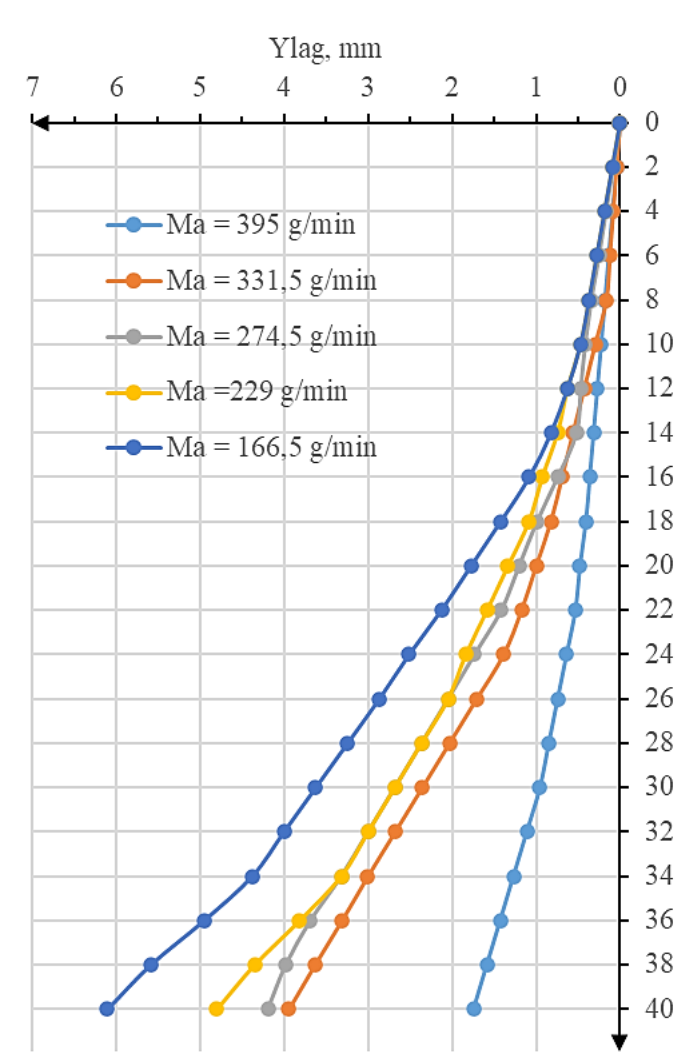

(c)

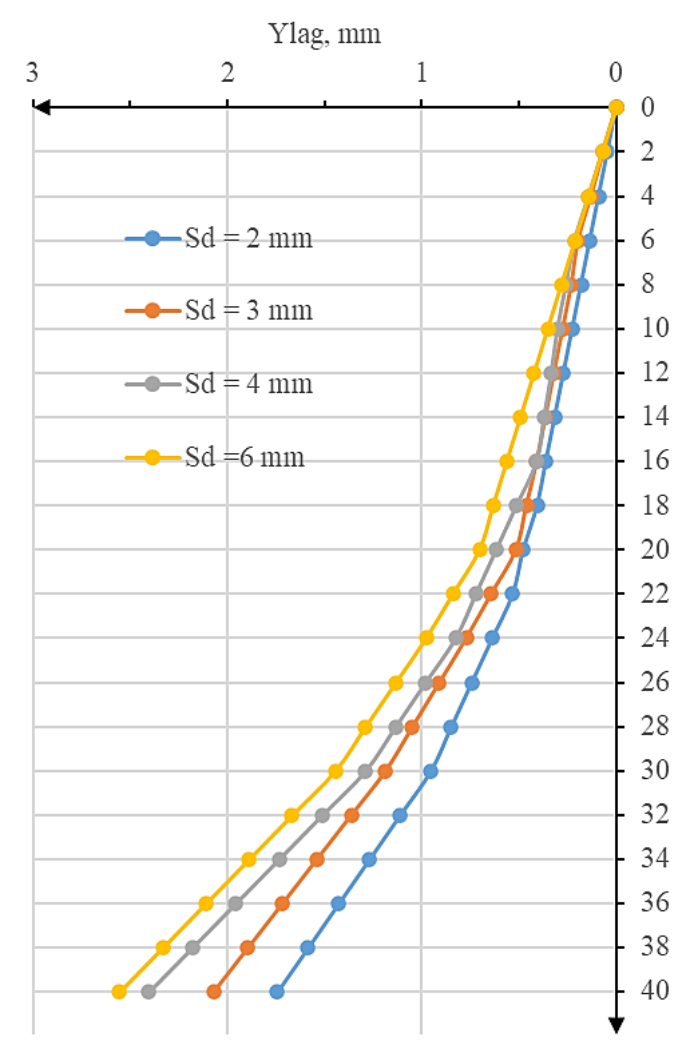

(d)

Figure 4: Influence of (a) operating pressure, (b) traverse speed, (c) abrasive mass flow rate and (d) stand-off distance on jet lagging [10]

\section{PREDICTIVE MODEL FOR JET LAGGING}

AWJC process involves a large number of variables that affect the cutting performance. Dimensional analysis is a powerful analytical technique in describing the relationship between physical engineering quantities (such as jet lagging) and independent variables. This technique is used to develop mathematical model for the jet lagging based on the experimental data for high-speed tool steel. The constants in the models were obtained by the regression analysis technique. These constants were statistically determined at minimum $95 \%$ confidence level. This model relates the jet lagging to four process variables, namely water pressure, nozzle traverse speed, abrasive mass flow rate and nozzle stand-off distance.

Mathematical model adopted for this research work will be as follows:

$$
\mathrm{Y}_{\mathrm{lag}}=\mathrm{a} \cdot \mathrm{h}^{\mathrm{b}} \cdot \mathrm{p}^{\mathrm{c}} \cdot \mathrm{U}^{\mathrm{d}} \cdot \mathrm{Ma}^{\mathrm{e}} \cdot \mathrm{Sd}^{\mathrm{f}}
$$

where $\mathbf{a}, \mathbf{b}, \mathbf{c}, \mathbf{d}, \mathbf{e}, \mathbf{f}$ are regression analysis coefficients.

The above model is valid for the operating parameters in the following range for practical purposes and machine limitations:

- Water pressure: 199,9 $\mathrm{MPa}<\mathrm{p}<413,7 \mathrm{MPa}$,

- Traverse speed: $5 \mathrm{~mm} / \mathrm{min}<\mathrm{U}<60 \mathrm{~mm} / \mathrm{min}$,

- $\quad$ Abrasive mass flow rate: $166,5 \mathrm{~g} / \mathrm{min}<\mathrm{ma}<395$ $\mathrm{g} / \mathrm{min}$ and

- Stand-off distance: $2 \mathrm{~mm}<\mathrm{Sd}<6 \mathrm{~mm}$.

The mathematical model that describes the impact of the corresponding machining parameters on the jet lagging was given for each diagram.

$$
\mathrm{Y}_{\text {lag }}=1.347 \cdot \mathrm{h}^{2.132} \cdot \mathrm{p}^{-1.251}
$$

Standard deviation of ( 3 ) is $\mathrm{R}=0.9948869$.

$$
\mathrm{Y}_{\mathrm{lag}}=0.0001017 \cdot \mathrm{h}^{1.945} \cdot \mathrm{U}^{1.046}
$$

Standard deviation of (4) is $\mathrm{R}=0.986002$.

$$
\mathrm{Y}_{\text {lag }}=1.022 \cdot \mathrm{h}^{1.821} \cdot \mathrm{Ma}^{-0.9575}
$$

Standard deviation of (5) is $\mathrm{R}=0.9948869$.

$$
\mathrm{Y}_{\mathrm{lag}}=0.001864 \cdot \mathrm{h}^{1.789} \cdot \mathrm{Sd}^{0.352}
$$

Standard deviation of (6) is $\mathrm{R}=0.9943339$.

It is shown that the model predictions are in good agreement with the experimental data with the deviations less than $3 \%$. Also, using the MATLab software package, multiple regression analysis was performed on the measured values of jet lagging, Ylag, and given in a 3D representation in figure 5, within the experimental range. 


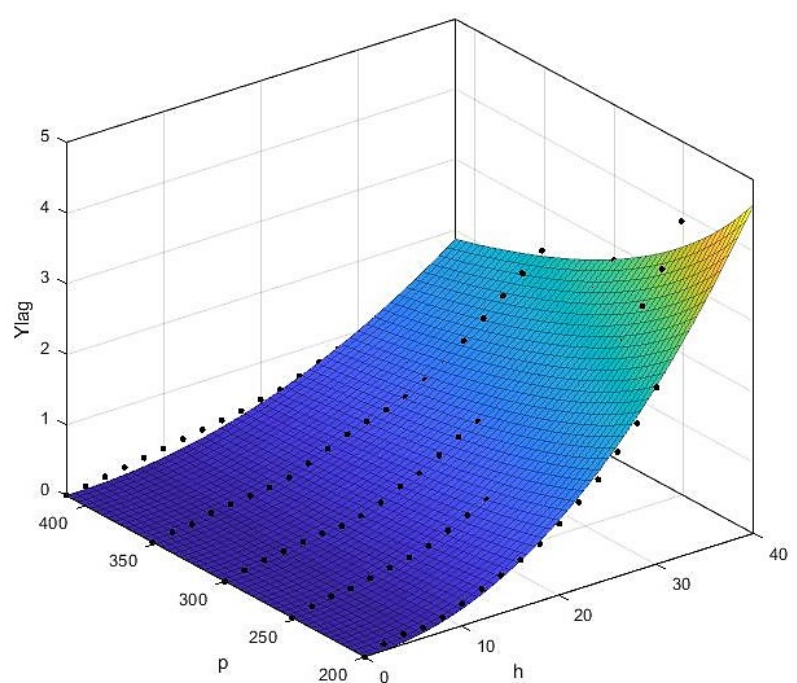

(a)

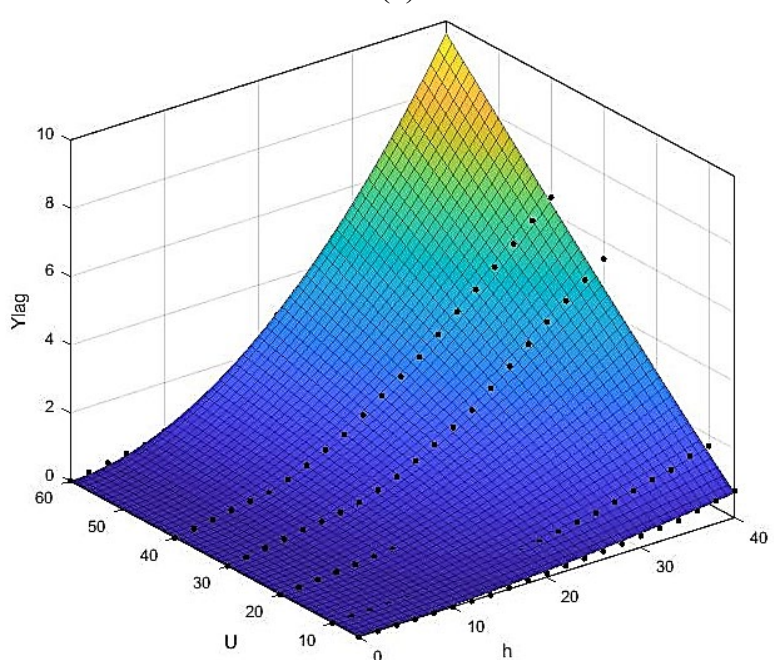

(b)

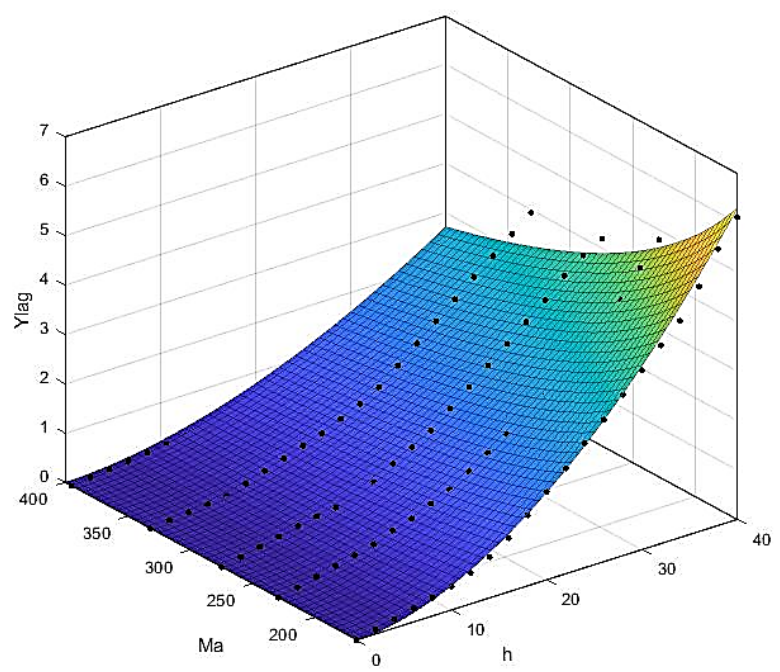

(c)

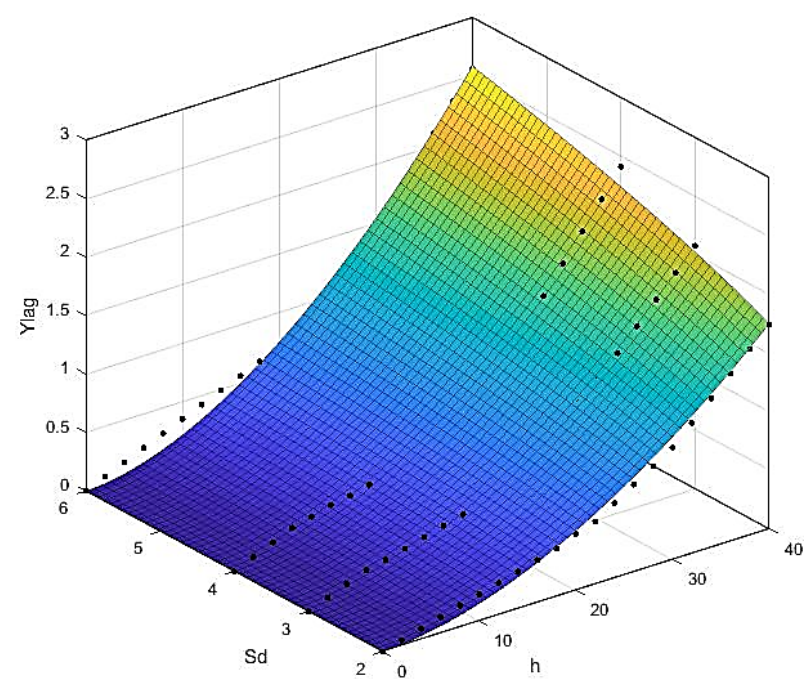

(d)

Figure 5: Influence of (a) operating pressure, (b) traverse speed, (c) abrasive mass flow rate and (d) stand-off distance on jet lagging

Based on the measured values in Table 2, the relationship between the jet lagging and operating pressure, stand-off distance, traverse speed, abrasive mass flow rate and depth of cut, is formed. This relationship is represented by a mathematical model described in (2).

$$
\mathrm{Y}_{\mathrm{lag}}=3.4656 \cdot \frac{\mathrm{h}^{1.4008} \cdot \mathrm{Sd}^{0.1086} \cdot \mathrm{U}^{1.1424}}{\mathrm{p}^{0.4053} \cdot \mathrm{Ma}^{1.1316}}
$$

Standard deviation of (7) is $\mathrm{R}=0.9702062$.

Figure 6 shows the observed values of the jet lagging versus the values of the jet lagging predicted by the model presented in (7).

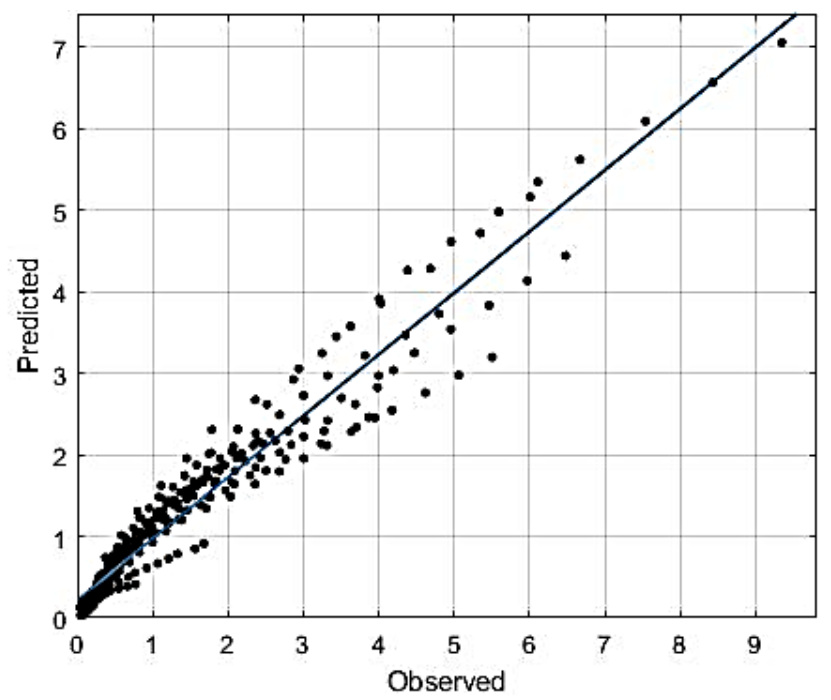

Figure 6: Observed versus predicted values of the jet lagging

\section{CONCLUSIONS}

Experimental investigations have been carried for the jet lagging in abrasive waterjet cutting of high-speed tool steel. The effects of different operational parameters such as: pressure, abrasive mass flow rate, traverse speed and nozzle stand-off distance on jet lagging have been investigated. 
The change of the jet lagging as the function of operating pressure, stand-off distance, traverse speed, and abrasive mass flow rate can be noted. With the increase of the traverse speed, there is an increase in the jet lagging. Furthermore, it can be observed that the increase of operating pressure and abrasive flow rate causes the decrease of the water jet lagging. This clearly suggests a firm correlation between the water jet lagging and the referred machining parameters. The influence of the depth of cut on the jet lagging is also significant. With the increasing depth of cut, the jet lagging also increases.

It is interesting that the exponent associated with the depth of cut, in all Equations (3, 4, 5 and 6), has a value of about 2 .

As a result of this study, it is observed that these operational parameters have a direct effect on jet lagging. It has been found that traverse speed has the most effect on jet lagging. An increase in traverse speed is associated with an increase in jet lagging. These findings indicate that the use of low traverse speed is preferred to obtain overall good cutting performance, but at the cost of productivity. Jet lagging constantly decreases as the mass flow rate increases. It is recommended to use a more mass flow rate to decrease jet lagging. Among the process parameters considered in this study traverse speed and abrasive mass flow rate have a similar effect on jet lagging, but one opposite from another. Stand-off distance has no apparent effect on jet lagging, but to achieve an overall cutting performance, a low stand-off distance should be selected.

From the experimental results, an empirical model for the prediction of jet lagging in the AWJC process of high-speed tool steel has been developed using regression analysis. Also, verification of the developed model for using it as a practical guideline for selecting the parameters has been found to agree with the experiments. Therefore, the need for extensive experimental work in order to select the magnitudes of the most influential abrasive waterjet cutting parameters on jet lagging of high-speed tool steel can be eliminated.

Based on the model from (7), it can be concluded that with the proper selection of the machining parameters, the desired values of the jet lagging can be achieved. The entire length of the cut does not need to be machined with such selected machining parameters, but only the parts of the path that make the curve, because major mistakes occur there.

From the (7), we can conclude that an increase of the depth of cut, stand-off distance and traverse speed leads to an increase of the jet lagging, and with an increase of operating pressure and abrasive mass flow rate jet lagging decreases.

The experiments were carried out on only one material, EN HS6-5-2, so that the obtained models are only valid for this material. It is necessary to carry out the experiments on different materials or the same material with different heat treatments to determine the effects of the mechanical properties of materials on the jet lagging.

It would also be interesting to carry out the experiments on the same material with different thicknesses and other mechanical properties, and to investigate this phenomenon and its dependencies.

\section{NOMENCLATURE}

$\begin{array}{cl}d_{a} & \text { Mean diameter of abrasive particles } \\ d_{j} & \text { Diameter of water jet } \\ h & \text { Depth of cut } \\ \text { Ma } & \text { Abrasive mass flow rate } \\ \mathrm{p} & \text { Working pressure } \\ \mathrm{U} & \text { Traverse speed } \\ \mathrm{Sd} & \text { Stand-off distance } \\ \mathrm{E} & \text { Materials Young's modulus } \\ \mathrm{Y}_{\text {lag }} & \text { Jet lagging } \\ \rho_{\mathrm{a}} & \text { Abrasives density } \\ \rho_{\mathrm{w}} & \text { Density of water } \\ \mathrm{s} & \text { Sample thickness } \\ \mathrm{a}, \mathrm{b}, \mathrm{c}, \mathrm{d}, \text { e f } & \text { Coefficients of regresion analysis }\end{array}$

\section{ACKNOWLEDGEMENTS}

This paper presents the results of research conducted on the doctoral research project "Investigation of Abrasive Water Jet Machining Parameters" which is financially supported by the Ministry of Science of Montenegro.

\section{REFERENCES}

[1] A. Hascalik, U. Caydas and H. Gurun, "Effect of Traverse Speed on Abrasive Waterjet Machining of Ti6Al-4V Alloy," Materials and Design, Vol. 28(6), pp. 1953-1957, (2007)

[2] A.W. Mombar and R. Kovacevic, "Principles of abrasive water jet machining", Springer, London, (1998)

[3] M.A. Azmir, A.K. Ahsan, "Investigation on glass/epoxy composite surfaces machined by abrasive waterjet machining”. Journal of Materials Processing Technology, Vol.198, pp 122-128, (2008)

[4] C. Ma, R.T. Deam. "A correlation for predicting the kerf profile from abrasive waterjet cutting". Experimental Thermal and Fluid Science, Vol.30, pp 337-343, (2006)

[5] P. Jankovic, M. Radovanovic, J. Baralic and B. Nedic, "Prediction model of surface roughness in abrasive water jet cutting of aluminum alloy", Balkan Tribology, Vol.19(4), pp 618-628, (2013)

[6] D. Arola and M. Ramulu, "Mechanism of material removal in abrasive waterjet machining", Proceedings of the 7th Water Jet Conference, pp. 46-64, (1993)

[7] M. Hasish, "A modeling study of metal cutting with abrasive waterjets", Journal of Engineering Materials and Technology, Vol. 106, pp. 88-100, (1984)

[8] J. Zeng, R. Heines and T.J. Kim, "Characterization of energy dissipation phenomena in abrasive water jet cutting", Proceedings of the 6th American Water Jet Conference, pp. 163-177, (1991) 
[9] M. Chithirai Pon Selvan and N. Mohana Sundara Raja, "A Machinability Study of Stainless Steel Using Abrasive Waterjet Cutting Technology", International Conference on Mechanical, Automobile and Robotics Engineering, Penang, Malaysia, (2012)

[10] R. Kurbegovic, M. Janjic, M. Vukcevic and D. Durovic, "Effect of abrasive water jet machining process parameters on jet lagging", 42. Jupiter conference, Belgrade, Serbia, pp. 3.81-3.87, (2020)

[11] V. Marušić, J. Baralić, B. Nedić i ostali, "Effect of machining parameters on jet lagging in abrasive water jet cutting", Technical Gazette, Vol. 20(4), pp. 677-682, (2013)

\title{
Zaostajanje mlaza kod abrazivnog vodenog mlaznog sečenja brzog alatnog čelika
}

\author{
Ramiz Kurbegović ${ }^{*}$, Mileta Janjić ${ }^{1}$ \\ ${ }^{1}$ Mašinski fakultet Univerziteta Crne Gore, \\ Podgorica (Crna Gora)
}

Abrazivna obrada vodenim mlazom je veoma efikasna nekonvencionalna metoda za konturno sečenje različitih vrsta materijala. Kao jedna od glavnih karakteristika kvaliteta površina obrađenih ovom metodom su zakrivljene linije koje se javljaju prilikom obrade. Ove linije su posledica odstupanja abrazivnog vodenog mlaza od njegove idealne vertikalne linije, zaostajanja mlaza koje su uzrok grešaka u mašinskoj obradi.

Cilj ovog rada je da se ispita uticaj parametara obrade na mlazno zaostajanje. Uzorci brzoreznog čelika EN HS6-5-2 (JUS c. 7680) su mašinski obrađeni abrazivnim vodenim mlazom pod različitim radnim pritiskom, brzinom pomeranja, protokom abrazivne mase $i$ rastojanjem odstupanja. Zaostajanje mlaza je mereno na dvadeset mesta uz dubinu reza i na osnovu ovih rezultata formiran je odnos između mlaznog zaostajanja i parametara obrade.

U cilju pravilnog odabira parametara procesa, razvijen je empirijski model za predviđanje kašnjenja mlaza pri abrazivnom rezanju brzoreznog čelika EN HS6-5-2 pomoću regresione analize. Ovaj razvijeni model je verifikovan eksperimentalnim rezultatima koji otkrivaju visoku primenljivost modela u okviru korišćenog eksperimentalnog opsega.

Ključne reči: Zaostajanje mlaza, Abrazivni vodeni mlaz, Empirijski model, Brzorezni alatni čelik, Regresiona analiza 